\title{
Investigation of anti-Neospora caninum antibodies and disease-related risk factors in goats")
}

\author{
ARMAGAN ERDEM UTUK, FUNDA ESKI* \\ Department of Parasitology, *Department of Obstetrics and Gynecology, \\ Faculty of Ceyhan Veterinary Medicine, University of Cukurova, 01330 Adana, Turkey
}

Utuk A. E., Eski F.

Investigation of anti-Neospora caninum antibodies and disease-related risk factors in goats

Summary

Neospora caninum is a parasitic protozoan that causes abortion, stillbirth, and premature culling in goats. The aims of this study were (i) to determine the prevalence of anti- $N$. caninum antibodies in goats in the Adana province of Turkey(ii), to identify risk factors for the disease, and (iii) to provide collective data on goat neosporosis. For this purpose, 383 sera were collected from goats of different breeds, ages, and sexes from 15 counties of Adana. A commercially available c-ELISA test kit was used to detect anti- $N$. caninum antibodies. To identify risk factors that influence the prevalence of neosporosis, an oral survey was conducted, and the data collected were evaluated by the logistic regression analysis. The prevalence was determined as $8.9 \%(34 / 383)$ at the individual level and $66.6 \%(10 / 15)$ at the flock level. Statistical analysis indicated that the co-presence of sheep, the animals' being of pure breed and the purchasing of animals from different flocks are the factors that increase the prevalence of neosporosis, while feeder disinfection decreases it.

Keywords: goat, neosporosis, risk factors, c-ELISA

Goat breeding is an important livestock industry in areas without suitable pastures, in macquis groves, and in mountainous regions of Turkey. One of essential components of goat breeding is to rear healthy offspring every year and to maintain the sustainability of the flock. Abortions that cannot be avoided are the biggest problem of goat breeding $(30,31)$. In goats, abortion is the loss of foetus at any time of gestation, and it usually occurs in the last 2 months of pregnancy. Various stress factors, nutritional disorders, poisonings, hormonal disorders, genetic factors, and infectious agents are major causes of abortion. Infectious agents are bacteria, viruses, fungi, and protozoa (31). According to the classical literature, the most important abortifacient protozoon in small ruminants is Toxoplasma gondii. Recent research, however, indicates that $N$. caninum may also be significant $(30,39)$.

Neospora caninum is a tissue-dwelling parasitic protozoon in the phylum Apicomplexa. Canidae are both the final and intermediate hosts of the parasite, while

1) This study was supported by the Scientific Research Coordination Unit of Cukurova University as project TSA-2017-8036, and a part of this study was presented orally at International Mediterranean Science and Engineering Congress (IMSEC 2017). ruminants are intermediate hosts. In the domestic cycle of $N$. caninum, the most important final and intermediate hosts are dogs and cows, respectively. Disease can be transmitted both horizontally and vertically. In the horizontal transmission, dogs are infected by eating the bradyzoite-contaminated meat of intermediate hosts, whereas the intermediate hosts are infected by oral uptake of water or food contaminated with sporulated oocysts. In pregnancy, vertical transmission occurs in two ways: as endogenous or exogenous. Endogenous transplacental transmission results from the reactivation of an existing persistent infection within a cow and leads to the birth of a persistently infected calf. Exogenous transplacental transmission, on the other hand, is the infection of a cow with oocysts, which leads to abortion $(17,39,44)$. Epidemic, endemic and sporadic abortions occur in infected cattle (32). Furthermore, early foetal deaths, stillbirths, and neonatal mortalities occur due to foetopahtic effects of the parasite. Foetal deaths result in economic losses due to increased calving intervals and delayed lactation. In addition, increased culling of valuable stock and decreased value of herds with high prevalence rates are considered as important problems for animal breeding (38). 


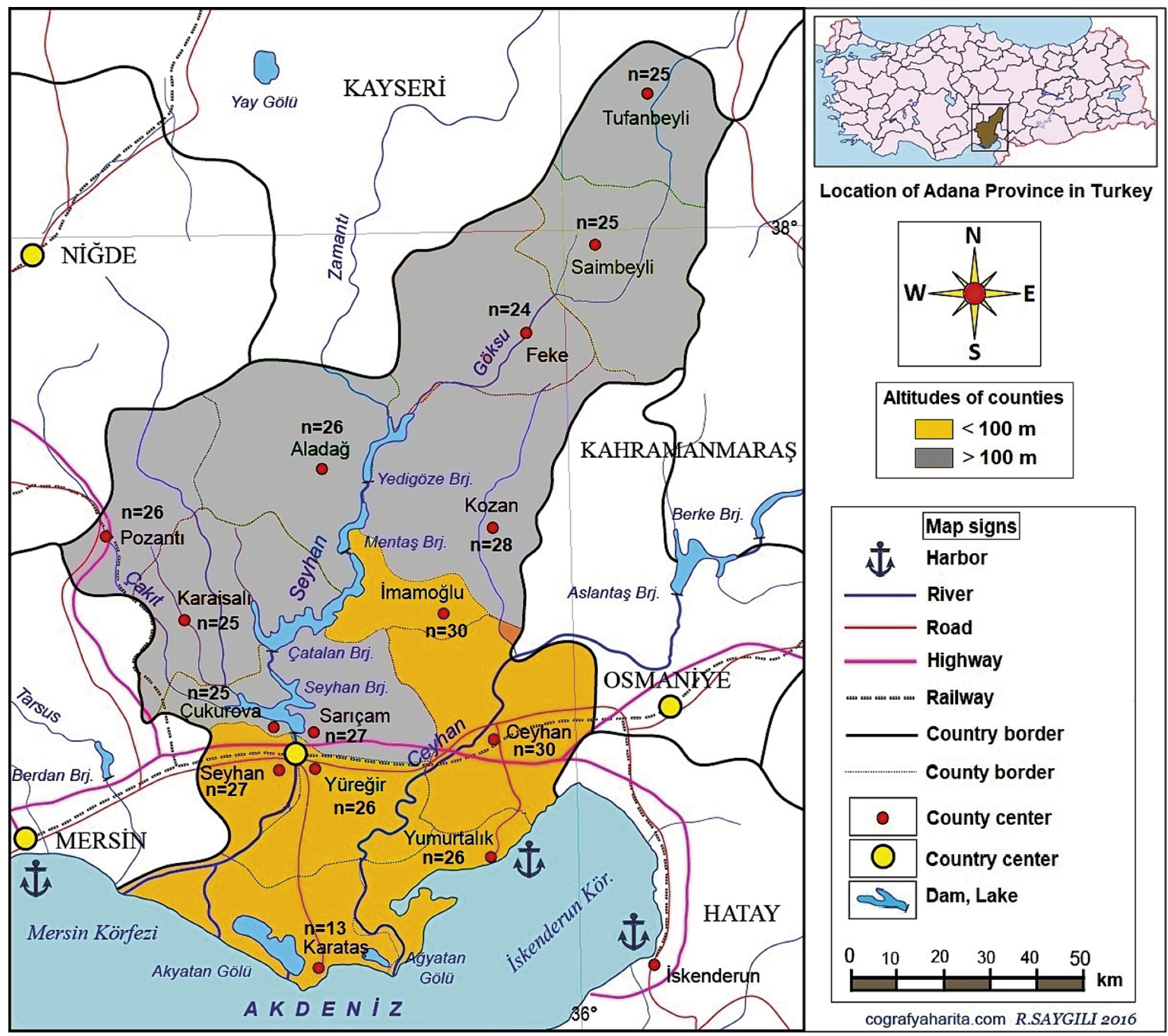

Fig. 1. Location of Adana, study areas and sample number (n)

Recent studies have shown that $N$. caninum causes abortions, foetal deaths, and stillbirths in goats, just as it does in cattle. Histopathologic and molecular techniques are used in the diagnosis of neosporosis, while the prevalence of the diseases is determined by serologic methods (c-ELISA, i-ELISA, NAT, IFAT) (39).

The aims of this study were (i) to determine the prevalence of anti- $N$. caninum antibodies in goats at individual and flock levels in the Adana province of Turkey, (ii) to identify risk factors for the disease, and (iii) to provide collective data on goat neosporosis.

\section{Material and methods}

Sera samples were obtained from 383 goats of different breeds, ages, and sexes from 15 counties of Adana, and stored at $-20^{\circ} \mathrm{C}$ until used (Fig. 1). While the counties were grouped according to their altitudes $(<100 \mathrm{~m}>100 \mathrm{~m})$, the goats were grouped according to breeds (hair goat and others), ages ( $\leq 3$ and $\geq 4$ years), and sexes (male and female).

To determine risk factors for neosporosis, the goat owners were asked questions about rearing systems, mix-breeding, pasture type, dominant breed, abortion and reproductive problems, disinfection, animal purchasing, and the presence of dogs. The data collected were evaluated by logistic regression analysis. The results of the statistical analysis are shown as an estimated relative risk (odds ratio-OR) and a $95 \%$ confidence interval $(\mathrm{CI})$. The statistical significance level was determined as $\mathrm{P}<0.05$ (Tab. 1).

A commercial c-ELISA test kit (VMRD, USA) was used to detect anti- $N$. caninum antibodies. Samples with percent inhibition values $\geq 30$ were confirmed as positive, and those with percent inhibition values $<30$ as negative.

This study was approved by the Ethics Committee of Adana Veterinary Control Institute (05.05.2016/1369). 


\section{Results and discussion}

At the end of the study, the prevalence was determined as $8.9 \%(34 / 383)$ at the individual level and $66.6 \%(10 / 15)$ at the flock level. Percent inhibition values ranged from 30.34056 to 95.41463 in positive samples and from -48.8132 to 29.72136 in negative samples. Statistical analysis showed that the co-presence of sheep, the animals' being of pure breed and the purchasing of animals from different flocks are factors that increase the prevalence of neosporosis, while feeder disinfection is a factor that decreases it $(\mathrm{P}<0.05)$ (Tab. 1).

According to the classical literature, T. gondii is the most important abortifacient protozoon in small ruminants $(30,31)$. In the $1990 \mathrm{~s}, N$. caninum was detected in stillborn and aborted goat fetuses, which created the awareness of goat neosporosis. After the 2000s, stud- ies focused on risk factors, prevention, and prevalence rates of $N$. caninum in goat flocks from different countries (39). Although there have been many studies on cattle neosporosis in recent decades, neosporosis has not been sufficiently investigated in other livestock and wild animals. Economic losses caused by $N$. caninum and the epidemiological characteristics of the parasite still remain unknown $(3,17,32)$.

According to different serological studies, the prevalence of the disease amounted to $6 \%$ in Africa, $0.7-7.23 \%$ in Asia, $0.47-15.5 \%$ in Europe, 3.8-5.8\% in North America, 1.05-17.7\% in South America (Tab. 2) and 0-25.9\% in Turkey (Tab. 3). According to our global assessment, the average seroprevalence of goat neosporosis was 4.54\% (118/2598) in Asia, $3.88 \%$ (147/3781) in Europe, 4.68\% (15/320) in North America, 7.29\% (684/9374) in South America, 5.99\%

Tab. 1. Risk factors for Neospora caninum infection in goats according to logistic regression analysis

\begin{tabular}{|c|c|c|c|c|c|c|c|c|}
\hline Variable & Category & No. tested & No. positive & $\%$ positive & Odds ratio & $95 \% \mathrm{CL}$ & $X^{2}$ & $P$ Value \\
\hline \multirow{2}{*}{ Altitude } & $<100 \mathrm{~m}$ & 179 & 17 & 9.5 & \multirow{2}{*}{1.14} & \multirow{2}{*}{$0.60-2.16$} & \multirow{2}{*}{0.160} & \multirow{2}{*}{0.689} \\
\hline & $>100 \mathrm{~m}$ & 204 & 17 & 8.3 & & & & \\
\hline \multirow{2}{*}{ Breed } & Hair goat & 230 & 17 & 7.4 & \multirow{2}{*}{1.56} & \multirow{2}{*}{$0.77-3.17$} & \multirow{2}{*}{1.572} & \multirow{2}{*}{0.210} \\
\hline & Others & 153 & 17 & 11.4 & & & & \\
\hline \multirow{2}{*}{ Sex } & Female & 341 & 31 & 9.1 & \multirow{2}{*}{1.27} & \multirow{2}{*}{$0.40-3.98$} & \multirow{2}{*}{0.175} & \multirow{2}{*}{0.675} \\
\hline & Male & 42 & 3 & 7.1 & & & & \\
\hline \multirow{2}{*}{ Age } & $\leq \mathbf{3}$ years & 192 & 16 & 8.3 & \multirow{2}{*}{1.14} & \multirow{2}{*}{$0.56-2.31$} & \multirow{2}{*}{0.141} & \multirow{2}{*}{0.707} \\
\hline & $\geq 4$ years & 191 & 18 & 9.4 & & & & \\
\hline \multirow{2}{*}{ Rearing system } & Semi-extensive & 358 & 31 & 8.7 & \multirow{2}{*}{1.43} & \multirow{2}{*}{$0.41-5.07$} & \multirow{2}{*}{0.322} & \multirow{2}{*}{0.570} \\
\hline & Intensive & 25 & 3 & 12.0 & & & & \\
\hline \multirow{2}{*}{ Co-presence of sheep } & Yes & 173 & 22 & 12.7 & \multirow{2}{*}{2.22} & \multirow{2}{*}{$1.13-4.36$} & \multirow{2}{*}{5.750} & \\
\hline & No & 210 & 12 & 5.7 & & & & $0.016^{*}$ \\
\hline & Common & 329 & 32 & 9.4 & 170 & 051525 & 0057 & 0254 \\
\hline Fasture type & Own & 74 & 2 & 5.6 & 1.10 & $0.04-0.00$ & 0.007 & 0.004 \\
\hline Dominant hreed & Pure & 309 & 32 & 10.4 & 383 & $03-1563$ & 4323 & 0038 * \\
\hline DUMIIIIIt Diecu & Crossbreed & 74 & 2 & 2.7 & 3.00 & $0.90-10.00$ & $4.5<3$ & 0.000 \\
\hline Hitomes ahoution & Yes & 256 & 26 & 10.2 & 101 & 0750 & 4561 & 0011 \\
\hline mistory or abortion & No & 127 & 8 & 6.3 & 1.01 & $0.10-5.40$ & 1.001 & 0.211 \\
\hline Uicton of notnoutum nublom & Yes & 172 & 16 & 9.3 & 100 & 05097 & 070 & 0709 \\
\hline . & No & 211 & 18 & 8.5 & 1.00 & $0.01-2.01$ & 0.070 & 0.102 \\
\hline Hictonu of infortility & Yes & 169 & 19 & 11.2 & 160 & $081-306$ & 2002 & 0148 \\
\hline 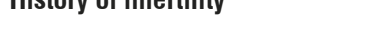 & No & 214 & 15 & 7.0 & 1.00 & $0.04-0.00$ & 2.092 & 0.140 \\
\hline Choltar dicinfoction & No & 148 & 18 & 12.2 & 170 & 002305 & 2200 & 070 \\
\hline 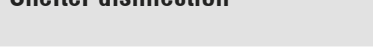 & Yes & 235 & 36 & 6.8 & 1.10 & 0.000 .00 & 0.200 & 0.070 \\
\hline Foodor dicinfoction & No & 334 & 34 & 10.2 & 111 & $107-115$ & 5.474 & $0.019 *$ \\
\hline e reeder disminection & Yes & 49 & 0 & 0 & 1.11 & $1.07-1.10$ & 0.414 & 0.019 \\
\hline Animal nurchasing & No & 304 & 22 & 7.2 & 229 & $108-487$ & 4903 & $0027 *$ \\
\hline Aintinar purtilasing & Yes & 79 & 12 & 15.2 & $2 . \angle 9$ & $1.00-4.01$ & 4.900 & 0.021 \\
\hline Dogs around the feeders & Yes & 292 & 26 & 8.9 & 101 & $0.47-215$ & 0001 & 0.970 \\
\hline 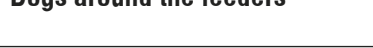 & No & 91 & 8 & 8.8 & 1.01 & $0.41-2.10$ & 0.001 & 0.010 \\
\hline
\end{tabular}

Explanation: * $-\mathrm{P}<0.05$ 
递  ○キ๐

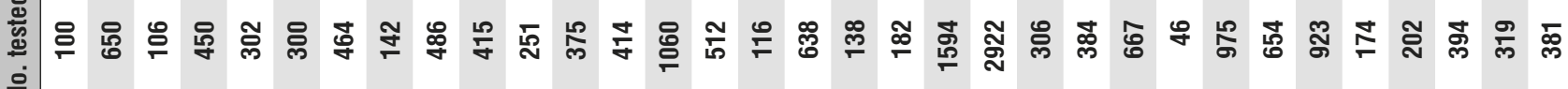
iे

क 1 䑻 1 , 1 \&

山 1

這

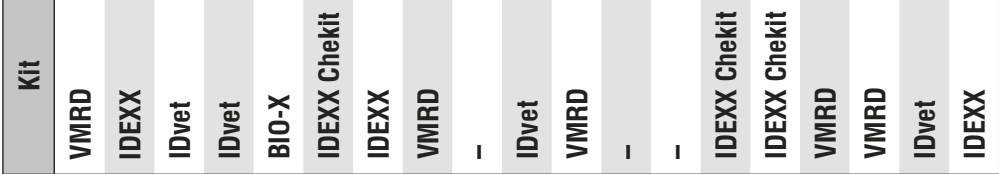

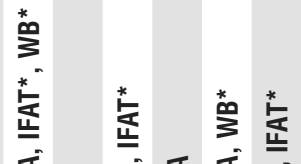

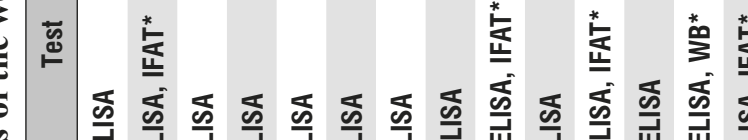

$\stackrel{n}{2}$

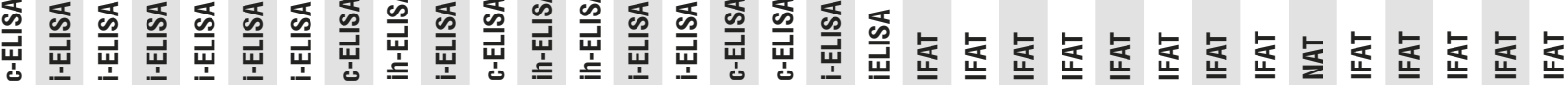

:

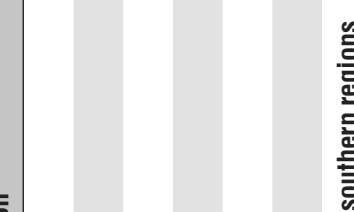

言

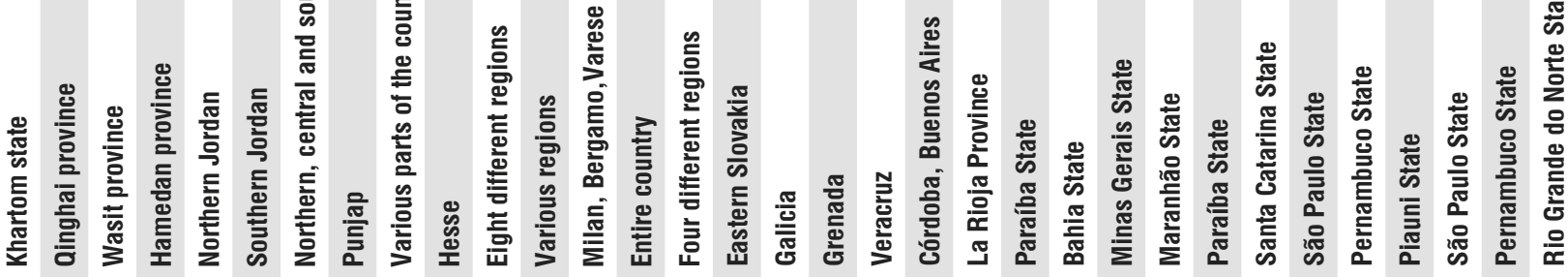

รี้

ప

:

ฮี

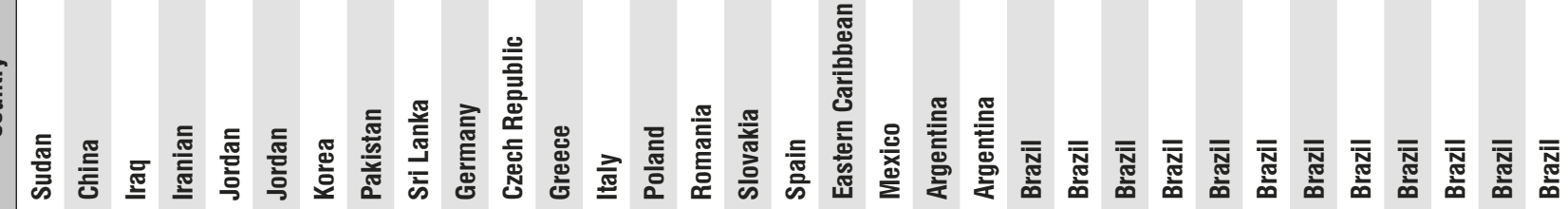

(5)

i்

言

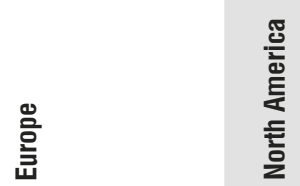

兽 
Tab. 3. Serological studies on caprine neosporosis in Turkey

\begin{tabular}{|c|c|c|c|c|c|c|c|c|c|c|c|c|}
\hline Region & Province & Test & Kit & Cut-off & SE & SP & $\begin{array}{l}\text { No. } \\
\text { tested }\end{array}$ & $\begin{array}{l}\text { No. } \\
\text { positive }\end{array}$ & $\begin{array}{c}\% \\
\text { positive }\end{array}$ & Reference & $\begin{array}{c}\text { Mean Prevalence } \\
(\%)\end{array}$ & $\begin{array}{c}\text { Turkey } \\
(\%)\end{array}$ \\
\hline \multirow{3}{*}{ Central Anatolia } & Kırşehir & c-ELISA & VMRD & $\geq \mathbf{3 0}$ & 96 & 99 & 41 & 1 & 2.43 & (40) & \multirow{3}{*}{$13.62(56 / 411)$} & \multirow{8}{*}{$\begin{array}{c}14.44 \\
(91 / 630)\end{array}$} \\
\hline & Konya & ih-ELISA & - & - & - & - & 189 & 8 & 4.2 & (45) & & \\
\hline & Niğde & C-ELISA & VMRD & $\geq \mathbf{3 0}$ & - & - & 181 & 47 & 25.9 & (8) & & \\
\hline \multirow{2}{*}{ Eastern Anatolia } & Elazığ & c-ELISA & VMRD & $\geq \mathbf{3 0}$ & 96 & 99 & 70 & 8 & 11.4 & (40) & \multirow{2}{*}{$13.79(12 / 87)$} & \\
\hline & Erzurum & c-ELISA & VMRD & $\geq \mathbf{3 0}$ & 96 & 99 & 17 & 4 & 23.5 & (40) & & \\
\hline Mediterranean & Karaman & ih-ELISA & - & - & - & - & 60 & 0 & 0 & (45) & $0(0 / 60)$ & \\
\hline \multirow{2}{*}{$\begin{array}{l}\text { Southeastern } \\
\text { Anatolia }\end{array}$} & Kilis & c-ELISA & VMRD & $\geq \mathbf{3 0}$ & 96 & 99 & 92 & 14 & 15.21 & (39) & \multirow{2}{*}{$8.45(23 / 72)$} & \\
\hline & Şanlıurfa & c-ELISA & VMRD & $\geq \mathbf{3 0}$ & - & - & 180 & 9 & 5 & (34) & & \\
\hline
\end{tabular}

Explanations: c-ELISA - Competitive Enzyme-Linked Immunosorbent Assay; ih-ELISA - In house ELISA; SE - Sensitivity; $\mathrm{SP}-$ Specificity

Tab. 4. Seroprevalence of goat neosporosis on particular continents and in the world

\begin{tabular}{|l|r|c|c|}
\hline \multicolumn{1}{|c|}{ Continent } & No. tested & No. positive & \% positive \\
\hline Africa & 100 & 6 & 6.00 \\
\hline Asia & 2598 & 118 & 4.54 \\
Europe & 3781 & 147 & 3.88 \\
North America & 320 & 15 & 4.68 \\
\hline South America & 9374 & 684 & 7.29 \\
\hline Total (World) & 16173 & 970 & 5.99 \\
\hline
\end{tabular}

(970/16173) globally (Tab. 4), and 14.44\% (91/630) in Turkey (Tab. 3). In this study, the individual prevalence was determined as $8.9 \%(34 / 383)$, which is below the average for Turkey (14.44\%), but above the world's average $(5.99 \%)$.

Flock-level prevalence was reported as $12-50 \%$ in Jordan $(1,2), 13.3 \%$ in Iran $(15), 32.1 \%$ in Italy (14), $0.9 \%$ in Poland (9), 38\% in Spain (11), 53.2\% in Argentina (26) and 16.4-75.2\% in Brazil $(5,33)$. In this study, we determined the flock-level prevalence as $66.6 \%(10 / 15)$, which is higher than the abovementioned rates, except for Brazil (5). Both individual and flock-level prevalence determined in the present study are above the world's average, and our results suggest that goat neosporosis is endemic in Adana and Turkey.

In previous studies, the relationship between the disease and various risk factors was examined, and conflicting results were obtained. In some studies, the age, breed, presence of dogs in flocks, and season are presented as risk factors important for the prevalence of neosporosis, which is not confirmed by some other studies $(1,2,6,8,13,14,16,22,26,34,37,39,41)$. As a general consensus, the sex of the animals is thought to have no effect on the prevalence of the disease $(6,12,14-16)$. In this study, statistical analysis indicates that the co-presence of sheep, the animals' being of pure breed and the purchasing of animals from different flocks are factors that increase the prevalence of neosporosis, while feeder disinfection decreases it $(\mathrm{P}<0.05)$ (Tab. 1).
Dramatic differences in the results of serological studies are due to different serological tests, cut-off values, specificity, and sensitivity rates, as well as wrong sampling $(39,40)$. Low cut-off values result in high sensitivity and low specificity, while high values have opposite effects (43). With regard to the ELISA kits and IFA tests used in different serological studies, it can be observed that cut-off values range from 30 to 50 , dilutions from $1 / 25$ to 100 , sensitivities of ELISAs from $95 \%$ to $100 \%$, and specificities from $95.1 \%$ to $100 \%$ (Tab. 2). It should be kept in mind that non-optimized serological tests may result in false positivity or negativity, and wrong sampling may also have adverse effects on test results.

In conclusion, to understand the epidemiology of neosporosis and to develop appropriate protection and control strategies, it is important to ensure harmonization among laboratories, to use the same test methods, cut-off values, and dilution ratios, as well as tests with the same specificity and sensitivity rates, and to keep proper records of the determinants of the disease related to the species, host, and environment in large scale studies at national and regional levels.

\section{References}

1. Abo-Shehada M. N., Abu-Halaweh M. M.: Flock-level seroprevalence of, and risk factors for, Neospora caninum among sheep and goats in northern Jordan. Prev. Vet. Med. 2010, 93, 25-32.

2. Al-Majali A. M., Jawasreh K. I., Talafha H. A., Talafha A. Q.: Neosporosis in sheep and different breeds of goats from southern Jordan: prevalence and risk factors analysis. Am. J. Anim. Vet. Sci. 2008, 3, 47-52.

3. Almería S.: Neospora caninum and wildlife. ISRN Parasitology 2013, 1-23, http://dx.doi.org/10.5402/2013/947347.

4. Anastasia D., Elias P., Nikolaos P., Charilaos K., Nektarios G.: Toxoplasma gondii and Neospora caninum seroprevalence in dairy sheep and goats mixed stock farming. Vet. Parasitol. 2013, 198, 387-390.

5. Andrade G. S., Bruhn F. R. P., Rocha C. M. B. M., Sa Guimaraes A., Gouveia A. M., Guimaraes A. M.: Seroprevalence for Neospora caninum in goats of Minas Gerais State, Brazil. Res. Vet. Sci. 2013, 94, 584-586.

6. Arraes-Santos A. I., Araújo A. C., Guimarães M. F., Santos M. F, Pena J. R., Gennari H. F. J., Azevedo S. M., Labruna S. S., Horta M. B., Maurício C.: Seroprevalence of anti-Toxoplasma gondii and anti-Neospora caninum antibodies in domestic mammals from two distinct regions in the semi-arid region of Northeastern Brazil. Vet. Parasitol. (Amst). 2016, 5, 14-18.

7. Bartova E., Sedlak K.: Toxoplasma gondii and Neospora caninum antibodies in goats in the Czech Republic. Vet. Med. 2012, 57, 111-114.

8. Cayvaz M., Karatepe M.: Niğde yöresi keçilerinde Neospora caninum'un seroprevalans1. Kafkas Univ. Vet. Fak. Derg. 2011, 17, 935-939. 
9. Czopowicz M., Kaba J., Szaluś-Jordanow O., Nowicki M., Witkowski L., Frymus T: : Seroprevalence of Toxoplasma gondii and Neospora caninum infections in goats in Poland. Vet. Parasitol. 2011, 178, 339-341.

10. Čobádiová A., Reiterová K., Derdáková M., Špilovská, S., Turčeková L', Hviščová I., Hisira V.: Toxoplasma gondii, Neospora caninum and ticktransmitted bacterium Anaplasma phagocytophilum infections in one selected goat farm in Slovakia. Acta Parasitol. 2013, 58, 541-546.

11. Díaz P., Cabanelas E., Díaz J. M., Viña M., Béjar J. P., Pérez-Creo A., Prieto A. López C. M., Panadero R., Fernández G.: Seroprevalence of Toxoplasma gondii and Neospora caninum in goats from North-Western Spain. Ann. Agric. Environ. Med. 2016, 23, 587-590.

12. Faria E. B., Gennari S. M., Pena H. F., Athayde A. C. R., Silva M. L. C. R., Azevedo S. S.: Prevalence of anti-Toxoplasma gondii and anti-Neospora caninum antibodies in goats slaughtered in the public slaughterhouse of Patos City, Paraíba State, Northeast region of Brazil. Vet. Parasitol. 2007, 149, 126-129.

13. Figliuolo L. P. C., Rodrigues A. A. R., Viana R. B., Rodrigues A. A. R., Viana R. B., Aguiar D. M., Kasai N., Gennari S. M.: Prevalence of anti-Toxoplasma gondii and anti-Neospora caninum antibodies in goat from São Paulo State, Brazil. Small Ruminant. Res. 2004, 55, 29-32.

14. Gazzonis A. L., Garcia G. A., Zanzani S. A., Mora L. M. O., Invernizzi A., Manfredi $M$. T.: Neospora caninum infection in sheep and goats from NorthEastern Italy and associated risk factors. Small Ruminant. Res. 2016, 140, 7-12.

15. Gharekhani J., Esmaeilnejad B., Rezaei H., Yakhchali M., Heidari H., Azhari M.: Prevalence of anti-Neospora caninum antibodies in Iranian goats. Ann of Parasitol. 2016, 62, 111-114.

16. Ghattof H. H., Faraj A. A.: Seroprevalence of Neospora caninum in goats in Wasit Province, Iraq. I.J.C.M.A.S. 2015, 4, 182-191.

17. Goodswen S. J., Kennedy P. J., Ellis J. T.: A review of the infection, genetics, and evolution of Neospora caninum: from the past to the present. Infect. Genet. Evol. 2013, 13, 133-150.

18. Gos M. L., Manazza J. A., Späth E. J. A., Pardini L., Fiorentino M. A., Unzaga J. M., Moré G., Venturini M. C.: Seroprevalence of Toxoplasma gondii and Neospora caninum infections in goats from two Argentinean provinces. Open Vet. J. 2017, 7, 319-322

19. Huerta-Peña J. C., Martínez-Herrera D. I., Peniche-Cardeña Á. E. J. Villanueva-Valencia M., Hernández-Ruiz S. G., Villagómez-Cortés J. A., Barradas-Piña F. T., Morales-Álvarez J. F., Flores-Castro R.: Seroprevalence and risk factors associated with Neospora caninum in goats from municipalities of the central region of Veracruz. Trop. Subtrop. Agroecosyst. 2011, 13, 445-454

20. Ibrahim A. M., Ismail A. A., Angara T. E. E.: Analysis of risk factors associated with seroprevalence of Toxoplasma gondii in dairy animals from Khartoum State, Sudan. Sudan J. Sc. Tech. 2015, 16, 19-28.

21.Iovu A., Györke A., Mircean V., Gavrea R., Cozma V.: Seroprevalence of Toxoplasma gondii and Neospora caninum in dairy goats from Romania. Vet. Parasitol. 2012, 186, 470-474.

22. Jung B., Lee S., Kwak D.: Evidence of Neospora caninum exposure among native Korean goats (capra hircus coreanae). Vet. Med. 2014, 59, 637-640.

23. Lima J. T. R., Ahid S. M. M., Júnior R. A. B., Pena H. F. J., Dias R. A., Gennari S. $M$.: Prevalência de anticorpos anti-Toxoplasma gondii E anti-Neospora caninum em rebanhos caprinos do município de Mossoró, Rio Grande Do Norte. Braz. J. Vet. Res. An. Sci. 2008, 45, 81-86.

24. Liu Z. K., Li J. Y., Pan H.: Seroprevalence and risk factors of Toxoplasma gondii and Neospora caninum infections in small ruminants in China. Prev. Vet. Med. 2015, 118, 488-492.

25. Modolo J. R., Stachissini A. V. M., Gennari S. M., Dubey J. P., Langoni H., Padovani C. R., Barrozo L. V., Leite B. L. S.: Frequência de anticorpos antiNeospora caninum em soros de caprinos do estado de São Paulo e sua relação com o manejo dos animais. Pesqui. Vet. Bras. 2008, 28, 597-600.

26. Moore D. P., Yaniz M. G., Odeón A. C., Cano D., Leunda M. R., Späth E. A. J., Campero C. M.: Serological Evidence of Neospora caninum Infections in goats from La Rioja Province, Argentina. Small Rum. Res. 2007, 73, 256-258.

27. Moraes L. M. B., Raimundo J. M., Guimarães A., Santos H. A., Junior M., de Lima G., Massard C. L., Machado R. Z., Baldani C. D.: Occurrence of antiNeospora caninum and anti-Toxoplasma gondii IgG Antibodies in goats and sheep in Western Maranhão, Brazil. Rev. Bras. Parasitol. V. 2011, 20, 312-317.

28. Naguleswaran A., Hemphill A., Rajapakse R. P., Sager H.: Elaboration of a crude antigen ELISA for serodiagnosis of caprine neosporosis: Validation of the test by detection of Neospora caninum-specific antibodies in goats from Sri Lanka. Vet. Parasitol. 2004, 126, 257-262.

29. Nasir A., Ashraf M., Khan M. S., Javeed A., Yaqub T., Avais M., Reichel M. P. Prevalence of Neospora caninum antibodies in sheep and goats in Pakistan J. Parasitol. 2012, 98, 213-215.

30. Noakes D. E., Parkinson T. J., England G. C. W.: Infertility in the ewe and doe (female goat), [in:] Arthur's Veterinary Reproduction and Obstetrics. $8^{\text {th }}$ Ed, Bailliere Tindall, London 2001, p. 570-575.
31. Pugh D. G.: Theriogenology of sheep and goats, [in:] Sheep and Goat Medicine $1^{\text {st }}$ Ed. Saunders, Philadelphia 2002, p. 175.

32. Reichel M. P., Ayanegui-Alcerreca M. A., Gondim L. F., Ellis J. T.: What is the global economic impact of Neospora caninum in cattle - the billion-dollar question? Int. J. Parasitol. 2013, 43, 133-142.

33. Santos C. S. A. B., Azevedo S. S., Soares H. S., Higino S. S. S., Santos F. A., Silva M. L. C. R., Pena H. F. J., Alves C. J., Gennari S. M.: Flock-level risk factors associated with Neospora caninum seroprevalence in dairy goats in a semiarid region of Northeastern Brazil. Small Rum. Res. 2013, 112, 239-242.

34. Sevgili M., Cimta I., Keski O.: Sanlıurfa yöresindeki keçilerde Neospora caninum enfeksiyonunun seroprevalansı. Turkiye Parazitol. Derg. 2003, 27, 249-251.

35. Sharma R. N., Bush J., Tiwari K., Chikweto A., Bhaiyat M. I.: Seroprevalence of Neospora caninum in sheep and goats from Grenada, West Indies. Open J. Vet. Med. 2015, 5, 219-223.

36. Tembue A. A. S. M., Ramos R. A. N., Sousa T. R., Albuquerque A. R., Costa A. J., Meunier I. M. J., Faustino M. A. G., Alves L. C.: Serological survey of Neospora caninum in small ruminants from Pernambuco State, Brazil. Rev. Bras. Parasitol. V. 2011, 20, 246-248.

37. Topazio J. P., Weber A., Camillo G., Vogel F. F., Machado G., Ribeiro A. Moura A. B., Lopes L. S., Tonin A. A., Soldá N. M.: Seroprevalence and risk factors for Neospora caninum in goats in Santa Catarina State, Brazil. Rev. Bras. Parasitol. V. 2014, 23, 360-366.

38. Trees A. J., Davison H. C., Innes E. A., Wastling J. M.: Towards evaluating the economic impact of bovine neosporosis. Int. J. Parasitol. 1999, 29, 1195-1200.

39. Utuk A. E., Eski F.: Detection of anti-Neospora caninum antibodies in a goat flock in Kilis Province of Turkey. I.J.V.S. 2017, 6, 114-117.

40. Utuk A. E., Simsek S., Piskin F. C., Balkaya I.: Detection of Neospora caninum IgG antibodies in goats in Elazig, Erzurum and Kirsehir Provinces of Turkey. Isr. J. Vet. Med. 2011, 66, 157-159.

41. Uzêda R. S., Pinheiro A. M., Fernández S. Y., Ayres M. C. C., Gondim L. F. P., Almeida M. A. O.: Seroprevalence of Neospora caninum in dairy goats from Bahia, Brazil. Small Rum. Res. 2007, 70, 257-259.

42. Villagra-Blanco R., Wagner H., Dolz G., Romero-Zúñiga J. J., Taubert A., Wehrend A., Hermosilla C.: First report on the seroprevalence of Neospora caninum in goats from the Federal State of Hesse, Germany. Berl. Munch. Tierarztl. Wschr. 2017, 130, 517-522.

43. Wapenaar W., Barkema H. W., Vanleeuwen J. A., McClure J. T., O'Handley R. M., Kwok O. C., Thulliez P., Dubey J. P., Jenkins M. C.: Comparison of serological methods for the diagnosis of Neospora caninum infection in cattle. Vet. Parasitol. 2007, 143, 166-173.

44. Williams D. J. L., Hartley C. S., Bjorkman C., Trees A. J.: Endogenous and exogenous transplacental transmission of Neospora caninum - how the route of transmission impacts on epidemiology and control of disease. Parasitology 2009, 136, 1895-1900

45. Zhou M., Cao S., Sevinc F., Sevinc M., Ceylan O., Liu M., Wang G., Moumoun P. F. A., Jirapattharasate C., Suzuki H., Nishikawa Y., Xuan X.: Enzyme-linked immunosorbent assays using recombinant TgSAG2 and NcSAG1 to detect Toxoplasma gondii and Neospora caninum-specific antibodies in domestic animals in Turkey. J. Vet. Med. Sci. 2016, 78, 1877-1881.

Corresponding author: Dr. Funda Eski, Department of Obstetrics and Gynecology, Faculty of Ceyhan Veterinary Medicine, Cukurova University, 01330, Adana, Turkey; e-mail: fndeski@hotmail.com 